\title{
Blood Vessel Replacement: 50 years of Development and Tissue Engineering Paradigms in Vascular Surgery
}

\author{
J. CHLUPÁČ ${ }^{1,2,3}$, E. FILOVÁ ${ }^{1,2}$, L. BAČÁKOVÁ ${ }^{1,2}$ \\ ${ }^{1}$ Center for Cardiovascular Research, ${ }^{2}$ Department of Growth and Differentiation of Cell \\ Populations, Institute of Physiology, Academy of Sciences of the Czech Republic, ${ }^{3}$ Transplant \\ Surgery Clinic, Institute for Clinical and Experimental Medicine, Prague, Czech Republic
}

Received September 1, 2009

Accepted October 30, 2009

\section{Summary}

The gold standard material in bypass surgery of blood vessels remains the patient's own artery or vein. However, this material may be unavailable, or may suffer vein graft disease. Currently available vascular prostheses, namely polyethylene terephthalate (PET, Dacron) and expanded polytetrafluoroethylene (ePTFE), perform well as large-caliber replacements, but their long-term patency is discouraging in small-caliber applications $(<6 \mathrm{~mm})$, such as in coronary, crural or microvessel surgery. This failure is mainly a result of an unfavorable healing process with surface thrombogenicity, due to lack of endothelial cells and anastomotic intimal hyperplasia caused by hemodynamic disturbances. An ideal small-diameter vascular graft has become a major focus of research. Novel biomaterials have been manufactured, and tissue-biomaterial interactions have been optimized. Tissue engineering technology has proven that the concept of partially or totally living blood vessels is feasible. The purpose of this review is to outline the vascular graft materials that are currently being implanted, taking into account cell-biomaterial physiology, tissue engineering approaches and the collective achievements of the authors.

\section{Key words}

Small-caliber vascular grafts • Synthetic polymers • Biomaterials

- Tissue engineering • Stem cells • Dynamic bioreactor • Shear stress

\section{Corresponding author}

Lucie Bačáková, Institute of Physiology, Academy of Sciences of the Czech Republic, Vídeňská 1083, CZ-142 20, Prague 4, Czech Republic. E-mail: lucy@biomed.cas.cz

\section{Introduction}

Atherosclerosis accounts for almost one half of all deaths in Europe (Stehouwer et al. 2009). Although advanced pharmacological and minimally-invasive techniques offer a growing therapy option (Met et al. 2008), a surgical bypass of blood vessels on the heart or on a lower extremity remains the procedure of choice in a number of patients (Fig. 1) (Guyton 2006, Norgren et al. 2007). This approach is also more cost-effective, and in particular preserves the quality of the patient's life better than primary amputation of a limb (Cheshire et al. 1992). A synthetic tube or a vascular prosthesis has to be implanted when the patient's own artery or vein is not available. After more than half a century of development work, the results achieved with currently available materials are not optimal in terms of healing and tissue regeneration.

Long-term patency rates of prosthetic grafts are satisfactory in large-caliber arteries $(>8 \mathrm{~mm})$, where thrombogenicity (i.e. disposition to blood coagulation) may be overcome by massive blood flow, and the 5-year patency of aorto-iliac substitutes is $90 \%$ (Brewster 1997). There is little difference between the results for prosthetic and autogenous (i.e. patient's own) material in medium-caliber replacements $(6-8 \mathrm{~mm})$, e.g. in carotid or common femoral arteries (Ricotta 2005). However, in small-caliber vessels $(<6 \mathrm{~mm})$, such as coronary arteries (heart), infrainguinal arteries (below the inguinal ligament), and particularly in low-flow infrageniculate 


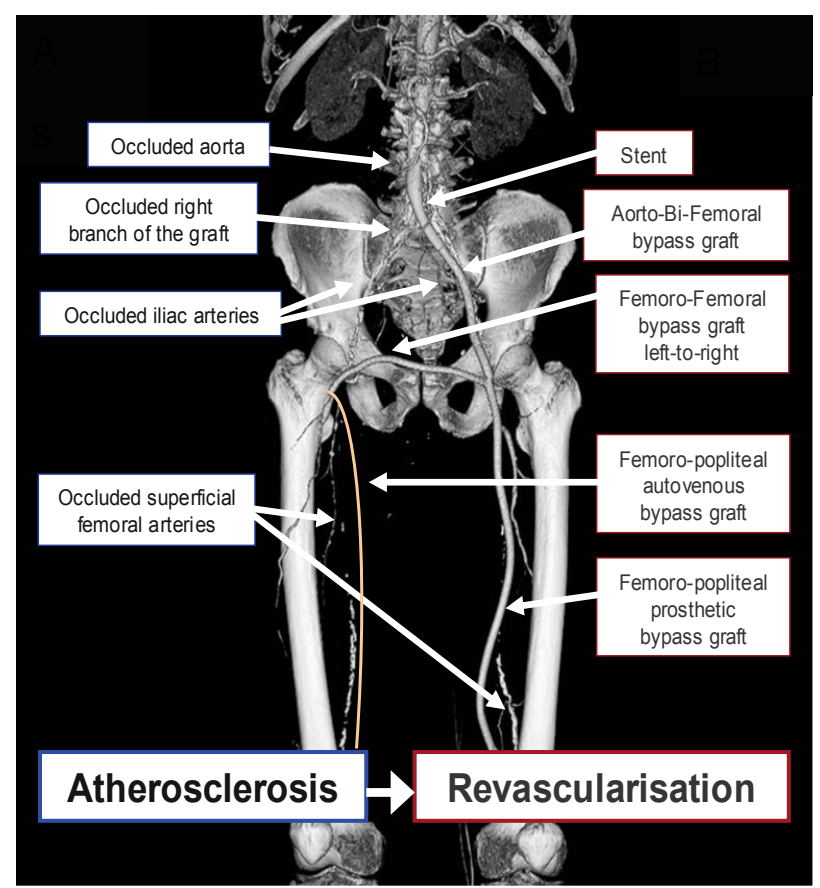

Fig. 1. Surgical repair of multilevel peripheral atherosclerotic disease.

arteries (below the knee joint), the outcomes of vascular prostheses are rather disappointing. Five-year primary patency of prosthetic (ePTFE) above-the-knee femoropopliteal bypass grafts is as low as $39 \%$, whereas autovenous bypasses (i.e. performed with own vein) have a rate of $74 \%$ (Klinkert et al. 2004). A summary of currently-used vascular replacements is shown in Table 1.

Currently available vascular grafts fail due to the thrombogenicity of the artificial surface and intimal hyperplasia (IH), which is located at distal anastomosis (Fig. 2) of prosthetic grafts (i.e. the site of the junction to the artery). Unlike animal models, most of the prosthetic blood-contacting surfaces remain uncovered by tissue in humans (Berger et al. 1972). The etiology of $\mathrm{IH}$, developing usually 2-24 months post implantation, is multifactorial and includes a compliance mismatch between a relatively rigid prosthesis and the more elastic native artery (Sarkar et al. 2006), graft/artery diameter mismatch, lack of endothelial cells (EC), surgical trauma and flow disturbances resulting in adaptive changes in the sub-endothelial tissue, characterized by proliferation and migration of vascular smooth muscle cells (VSMC) from media to intima, and synthesis of extracellular matrix (ECM) proteins (Haruguchi and Teraoka 2003).

To overcome these fundamental inconveniencies, novel biomaterials research (Shin and Mikos 2003) and particularly tissue engineering modalities are increasingly being adopted (Isenberg et al. 2006).

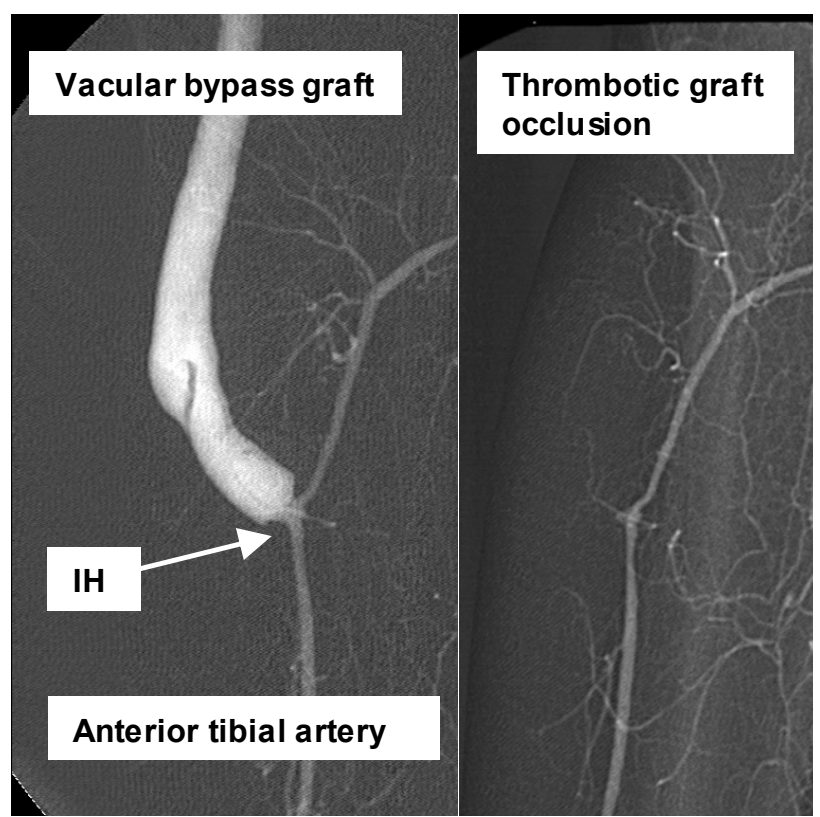

Fig. 2. Intimal hyperplasia (IH) in distal anastomosis of a vascular graft, causing thrombosis and occlusion.

Promising and clinically proven outcomes have been achieved with biohybrid and tissue-engineered vascular grafts.

An ideal vascular graft would possess the following characteristics: mechanical strength and compliance to withstand long-term hemodynamic stresses; non-toxicity; non-immunogenicity; biocompatibility; "off-the-shelf" availability in various sizes for emergency care; operative suturability and simplicity of surgical handling; resistance to in vivo thrombosis; ability to withstand infection; complete incorporation into the host tissue with satisfactory graft healing and ability to grow when placed in children (Kakisis et al. 2005), and, last but not least, reasonable manufacturing costs. The task is so demanding and the potential rewards are so great that research in the field of small-caliber vascular substitutes has been compared with the search for the Holy Grail (Conte 1998).

The aim of this review is to outline the characteristics and drawbacks of currently-used vascular substitutes, with special emphasis on the physiological cellular response to materials and on vascular tissue engineering approaches, based on the collective experience of the authors.

\section{Historical background}

The history of vascular surgery tracks progress made in suturing and replacing damaged vessels. In 
Table 1. Vascular substitutes in clinical use according to body region.

\begin{tabular}{|c|c|c|c|c|c|}
\hline \multirow{3}{*}{$\begin{array}{l}\text { Vascular } \\
\text { substitute } \\
\text { choice }\end{array}$} & \multicolumn{5}{|c|}{ Vascular regions } \\
\hline & $\begin{array}{l}\text { Large-caliber } \\
\text { arteries } \\
\text { ( } \geq 8 \mathrm{~mm})\end{array}$ & $\begin{array}{l}\text { Medium-caliber } \\
\text { arteries } \\
(6-8 \mathrm{~mm})\end{array}$ & $\begin{array}{l}\text { Small-caliber } \\
\text { arteries } \\
(\leq 6 \mathrm{~mm})\end{array}$ & $\begin{array}{l}\text { Venous } \\
\text { reconstructions }\end{array}$ & $\begin{array}{l}\text { Hemodialysis arterio- } \\
\text { venous access }\end{array}$ \\
\hline & $\begin{array}{l}\text { Aorta, arch vessels, } \\
\text { iliac and common } \\
\text { femoral arteries }\end{array}$ & $\begin{array}{l}\text { Carotid, subclavian, } \\
\text { common femoral, } \\
\text { visceral and above- } \\
\text { the-knee arteries }\end{array}$ & $\begin{array}{l}\text { Coronary, below- } \\
\text { the-knee, tibial and } \\
\text { peroneal arteries }\end{array}$ & $\begin{array}{l}\text { Superior and inferior } \\
\text { vena cava, ilico- } \\
\text { femoral veins, portal } \\
\text { vein, visceral veins }\end{array}$ & Upper $>$ lower extremity \\
\hline $1^{s t}$ choice & $\begin{array}{l}\text { Prosthesis (Dacron, } \\
\text { ePTFE) }\end{array}$ & $\begin{array}{l}\text { Prosthesis or autograft } \\
\text { (equal) }\end{array}$ & $\begin{array}{l}\text { Arterial or venous } \\
\text { autograft }\end{array}$ & $\begin{array}{l}\text { Saphenous spiral } \\
\text { vein graft, deep } \\
\text { venous autograft }\end{array}$ & Native material \\
\hline $2^{\text {nd }}$ choice & $\begin{array}{l}\text { Allograft, deep } \\
\text { venous autograft }\end{array}$ & Prosthesis or autograft & $\begin{array}{l}\text { Composite graft, } \\
\text { vein interposition, } \\
\text { prosthesis (ePTFE, } \\
\text { Dacron), allograft, } \\
\text { biosynthetic }\end{array}$ & $\begin{array}{l}\text { Allografts, ePTFE, } \\
\text { Dacron, biografts }\end{array}$ & $\begin{array}{l}\text { ePTFE, PU, xenografts, } \\
\text { biografts, TEBV (clinical } \\
\text { trial) }\end{array}$ \\
\hline
\end{tabular}

ePTFE (expanded polytetrafluoroethylene), PU (polyurethane), TEBV (totally-engineered blood vessels).

ancient times, vascular interventions were limited to compressing and cauterizing injured vessels to control bleeding. Ambrose Paré developed a vessel ligature in the $15^{\text {th }}$ century, but surgical repair of vessels did not begin until 1759, when Hallowell and Lambert repaired a brachial artery injury with a suture. The first vascular anastomosis (connection of blood vessels) was performed by Nicholas Eck as a porto-caval shunt in dogs in 1877 (Starzl 2003). Carrel and Guthrie optimized the vascular anastomosis transplantation technique and even tissue culture for organ replacement in the early 1900s, and Alexis Carrel received the Nobel Prize for Physiology or Medicine in 1912.

Goyannes first used an autogenous popliteal vein graft for popliteal aneurysm repair in 1906. A femoropopliteal bypass with a reversed saphenous vein graft was first performed by Kunlin in 1948, initiating a very successful era for this type of graft that has lasted until the present day (Lopez and Ginzberg 2008). At the same time, the first fresh arterial allografts (foreign tissue of the same species) began to be used in human vascular reconstructive surgery (Gross et al. 1948). An artificial vascular prosthesis was first implemented as an aortic replacement with a Vinyon " $\mathrm{N}$ " tube in a dog experiment (Voorhees et al. 1952). The same material was implanted in humans to replace an aneurysm (dilation) of the abdominal aorta (Blakemore and Voorhees 1954), leading to rapid progress in vascular surgery and prostheses research and use (Sauvage 1986).

\section{Arterial replacements}

\section{Biological vascular grafts}

The gold standard for vascular replacement remains the autologous native vessel, which possesses the most physiological properties. In coronary artery bypass grafting $(\mathrm{CABG})$, the internal mammary artery and the radial artery are superior to a greater saphenous vein graft (SVG), which is also often used (Beghi et al. 2002). In the case of lower limb or peripheral bypass surgery, the material of choice is also greater saphenous vein (vena saphena magna). It can be cleansed of valves and anastomosed in situ, so that the vasa vasorum remain intact (Kachlík et al. 2007) and the blood flow direction is reversed. In this type of graft, preservation of desired endothelial properties can be expected; however, several studies have failed to confirm superiority to the more widespread ex vivo reversed setting of the SVG (Lawson et al. 1999). It should be noted that, despite good clinical performance, SVG is also liable to atherosclerosis and intimal hyperplasia occurring throughout the length (Sarjeant and Rabinovitch 2002). In addition, almost 30$40 \%$ of patients lack an appropriate saphenous vein (Faries et al. 2000) due to previous phlebitis, vessel removal, varicosities, hypoplasia or anatomical unsuitability. Additionally, any surgical vessel harvest is associated with indispensable donor site morbidity (Swenne et al. 2006).

Alternatives include the use of other native vascular materials only in carefully selected indications, 
and sometimes with limited clinical performance: arteries, such as the right gastroepiploic artery for coronary application (Sasaki 2008), and veins, such as the lesser saphenous vein (vena saphena parva) (Chang et al. 1992), arm veins (Calligaro et al. 1997) for coronary and peripheral bypasses, or deep leg veins (Ali et al. 2009) for infected aortic graft replacement, visceral revascularization or even primary lower limb bypass.

Although the use of fresh (cold-stored) or cryopreserved homografts (i.e. human allografts from cadaver donors) was abandoned in the early 1960s because of difficulties in preserving them, late graft deterioration, aneurysm formation and the anticipated availability of synthetic prostheses, they have been reintroduced for managing aortic prosthetic graft infection (Kieffer et al. 2004), lower extremity primary revascularization (Dardik et al. 2002, Fahner et al. 2006, Matia et al. 2007) and simultaneous or sequential revascularization surgery in solid organ transplantrecipients (Matia et al. 2008). Although allografts are not routinely used (usually in limb-threatening situations, in redo surgery or in an infected field), some studies suggest improved patency of these grafts, e.g. in the case of preserved externally-supported human umbilical vein (harvested from newborns) when compared to ePTFE (Johnson and Lee 2000).

The application of heterografts (xenografts, i.e. tissue from different species) (Schmidt and Baier 2000) involves mainly studies on alternative hemodialysis vascular access. Although bovine carotid artery heterografts did not show superiority to PTFE (Hurt et al. 1983), and decellularized bovine ureteric grafts have been implanted with ambiguous results (Chemla and Morsy 2009), glutaraldehyde-crosslinked bovine mesenteric vein provided a considerable reduction in infection, thrombosis and reintervention rate (Katzman et al. 2005). Importantly, decellularized natural tissue of allogenic (human) or xenogenic (animal) origin serves as a scaffold for cell seeding within the scope of tissue engineering of vascular grafts (Dahl et al. 2003). A summary of biological vascular conduit materials is presented in Table 2 .

\section{Synthetic vascular grafts}

For more than 50 years, two polymers have been used for synthetic vascular prostheses: 1) polyethylene terephthalate (PET), Terylene or Dacron, and 2) polytetrafluoroethylene (PTFE), Teflon or Gore-Tex. Both of these molecules are highly crystalline and hydrophobic. Prosthetic rings or coils can be applied to the external surface of both materials to resist kinking and compression in anatomically required positions (long bypasses, grafts crossing the joint or body midline).

$\mathrm{PET} / \mathrm{Dacron}$ (polyethylene terephthalate, [-O-C $\left.=\mathrm{O}-\mathrm{C}_{6} \mathrm{H}_{4}-\mathrm{O}-\mathrm{C}=\mathrm{O}-\mathrm{CH}_{2}-\mathrm{CH}_{2}-\right]$ ) was introduced in England in 1939, and was further developed and patented as Dacron by DuPont in 1950. It is a thermoplastic polymer resin of the polyester family and is used in synthetic fibers of round cross-section. These fibers are bundled into multifilament yarns, which can be woven (over-and-under pattern) or knitted (looped fashion) into textile vascular graft fabrics and tubes. A crimping technique (an undulating surface) is sometimes used to increase distensibility and kink-resistance. The porosity of a textile Dacron graft is defined by water permeability, which is greater for knitted Dacron. Knitted Dacron is impregnated with albumin, collagen or gelatin to make it more impervious, to decrease the porosity/permeability, and to avoid the need for blood preclotting prior to implantation. Depending on the cross-linking agent (formaldehyde or glutaraldehyde), the albumin impregnation is degraded 2 to 8 weeks after implantation (Marois et al. 1996). Although collagen impregnation increased platelet deposition and delayed the healing process in a dog experiment (Guidoin et al. 1996), a prospective randomized trial with aorto-iliac prostheses indicated that collagen impregnation does not stimulate the coagulation cascade more than conventional Dacron (De Mol Van Otterloo et al. 1991). There are no differences in clinical graft patency between woven and knitted Dacron, when used as an aorto-iliac bypass graft (Quarmby et al. 1998). Dacron is reported to dilate over time, but direct association with graft complications and failure has been rare (Blumenberg et al. 1991).

Host reactions to the vascular prosthesis start immediately after restoration of blood circulation. The tissue-prosthesis and blood-prosthesis interfaces are complex microenvironments, and the physico-chemical properties of the surface of the prosthesis, such as charge, energy, wettability and roughness, may be responsible for the graft patency. The first step is the plasma protein adsorption/desorption process typical for any blood/material interface (Vroman and Adams 1969), followed by platelet deposition, white blood cell and erythrocyte adhesion, and eventually endothelial and smooth muscle cell migration. Fibrin deposits, which contain platelets and blood cells, build up during the first few hours to days after implantation. They are stabilized 
Table 2. Biological vascular grafts in clinical use.

\begin{tabular}{|c|c|c|c|c|c|}
\hline & \multicolumn{5}{|c|}{ Biological vascular grafts } \\
\hline & \multicolumn{2}{|l|}{ Autografts } & \multicolumn{2}{|c|}{ Allografts (homografts) } & \multirow{2}{*}{$\begin{array}{l}\text { Xenografts } \\
\text { (heterografts) } \\
\end{array}$} \\
\hline & Arterial & Venous & Arterial & Venous & \\
\hline Advantages & $\begin{array}{l}\text { Closest approximation, } \\
\text { less diameter mismatch, } \\
\text { internal mammary } \\
\text { artery anatomically } \\
\text { nearby, excellent } \\
\text { function }\end{array}$ & $\begin{array}{l}\text { Durable and versatile, good } \\
\text { results, infection } \\
\text { resistance, relative } \\
\text { availability }\end{array}$ & \multicolumn{3}{|c|}{$\begin{array}{l}\text { Off the shelf availability, better resistance to infection, } \\
\text { transplant-recipient patients }\end{array}$} \\
\hline Disadvantages & $\begin{array}{l}\text { Availability, vasospasm } \\
\text { (radial artery), donor } \\
\text { site morbidity }\end{array}$ & $\begin{array}{l}\text { Availability, harvest injury, } \\
\text { vein graft disease }\end{array}$ & \multicolumn{3}{|c|}{$\begin{array}{l}\text { Antigenicity, graft deterioration, early occlusions, chronic } \\
\text { rejection, intake of drugs, infection risk }\end{array}$} \\
\hline Healing & $\begin{array}{l}\text { Intimal thickening, } \\
\text { myointimal hyperplasia } \\
\text { (radial artery) }\end{array}$ & $\begin{array}{l}\text { Endothelial desquamation, } \\
\text { vein dilation, wall } \\
\text { thickening, arterialization, } \\
\text { re-endothelialization }\end{array}$ & \multicolumn{3}{|c|}{ Endothelial denudation, immune response, fibrotization } \\
\hline First use & $\begin{array}{l}\text { Jaboulay and Briau } \\
1896\end{array}$ & Goyannes 1906 & Gross et al. 1948 & Linton 1 & \\
\hline Reviewe.g. & Nezic et al. 2006 & Cooper et al. 1996 & Fahner et al. 2006 & Dardik & $\begin{array}{l}\text { Schmidt and } \\
\text { Baier } 2000\end{array}$ \\
\hline
\end{tabular}

over a period of up to 18 months and form an inner compacted fibrin layer. Fibrin also fills the interstices within the graft wall. Generally, this fibrin/platelet pseudointima remains acellular; however, after 5 months, capillaries and fibroblasts can grow into the tight intersticial spaces even in humans (Stewart et al. 1975) and reach the inner fibrin layer. Only a few sparse small islands of endothelialization appeared in areas remote from the anastomosis region on woven excised Dacron grafts (Wu et al. 1995). External fibrin matrix surrounding the graft is gradually invaded by macrophages, and granulation tissue and foreign-body giant cells (FBGC) are usually seen under the external surrounding connective tissue capsule (Rahlf et al. 1986). In the case of knitted Dacron, endothelial islands can occasionally be observed on human explants during redo surgery or autopsy 1-11 years after implantation (Shi et al. 1997). Mature endothelium and a well-developed smooth muscle layer, described only in animal studies, is attributable to extended transanastomotic ingrowth rather than a midgraft healing process (Clowes et al. 1987, Zacharias et al. 1987).

The structure of knitted and, to a lesser extent, also woven Dacron allows a certain degree of transmural tissue ingrowth. However, the compacted inner fibrin layer forms a barrier and, even if the barrier is overcome by undifferentiated connective tissue, the capillaries remain unconnected to the poorly endothelialized blood surface (Herring et al. 1979, Xue and Greisler 2003).

PTFE (polytetrafluoroethylene, $\left[-\mathrm{CF}_{2}-\mathrm{CF}_{2}-\right]$ ) was patented by DuPont as Teflon in 1937, and ePTFE was patented by Gore as Gore-Tex in 1969. ePTFE is an expanded polymer which is manufactured by a heating, stretching, and extruding process resulting in a nontextile porous tube composed of irregular-shaped solid membranes ("nodes"). The molecule is relatively biostable, i.e. less prone to deterioration in biological environments than PET (Guidoin et al. 1993a,b), and the graft surface is electronegative, which minimizes its reaction with blood components. It is characterized by a node-fibril structure, and its average porosity is described by the internodal distance (IND), which is usually 30 to $90 \mu \mathrm{m}$. However, the actual available ingrowth spaces between fibrils are much smaller than IND.

Optimal IND of $60 \mu \mathrm{m}$ (high porosity) was experimentally proposed for tissue ingrowth and endothelialization of $4 \mathrm{~mm}$ ePTFE grafts in a baboon model (Golden et al. 1990). Though a human trial with high-porosity ePTFE showed capillary ingrowth, it did not extend more than half the distance from the outside, and did not produce an endothelial lining (Kohler et al. 1992). Human host responses to standard low-porosity 
ePTFE (IND $\leq 30 \mu \mathrm{m}$ ) material are similar to the responses to Dacron grafts: a thin fibrin coagulum or amorphous platelet-rich material develops over time, and a lack of luminal surface endothelial cellular coverage is found after human implants. Collagenous external encapsulation develops within 1 to 6 months, penetrating the material structure with minimal cellular infiltration (Guidoin et al. 1993a). Systematic evaluation and metaanalysis of randomized controlled trials comparing Dacron and ePTFE showed no evidence of an advantage of one material over the other (Roll et al. 2008).

Polyurethanes (PU) comprise a large family of elastic polymers containing a urethane [-NH-(CO)-O-] group. Polyurethanes were originally developed in Germany in the 1930s. They were commercialized by DuPont in 1962, and have been available for biomedical applications since the 1960s (Boretos and Pierce 1967). Generally, they are copolymers consisting of three different monomers: crystalline (hard) and amorphous (soft) segments, the former accounting for rigidity and the latter for flexibility, which can be varied by the manufacturer. The third monomer serves as a chain extender (Zdrahala 1996). The disadvantage of the first generation polyester-based PU was hydrolytic biodegradation, which resulted in abortion of one of the clinical trials (Zhang et al. 1997). The next generation of polyether-based PU, which is hydrolysis-resistant but more susceptible to oxidation, underwent succesful clinical assessment as hemodialysis access graft (Glickman et al. 2001), and received Food and Drug Administration (FDA) approval in 2000.

The latest generation of polycarbonate-based $\mathrm{PU}$ is hydrolytically and oxidatively stable, and promoted faster luminal endothelialization and less neointimal formation as small-calibre vascular prostheses in a rat experiment compared to ePTFE (Jeschke et al. 1999). After 36-month implantation in aorto-iliac position in dogs, a histological analysis of poly(carbonate-urea) PU grafts showed well-developed neointima only in distal anastomosis, only minor hydrolysis of the amorphous segments and, in addition, the grafts retained their compliance with time - a feature not observed in Dacron or ePTFE. These promising results led to a phase I clinical trial (Seifalian et al. 2003).

According to their microstructure, polyurethanes can be divided into fibrillar or foamy. Both structures tend to lack communicating spaces for potential capillary ingrowth. Upon implantation, the blood surface of the fibrillar PU is covered by a fibrin layer that is thinner than on knitted Dacron, and the outer surface is encapsulated by scar formation containing FBGC. In microporous foamy PU with $15 \mu \mathrm{m}$ pore size, relatively little capillary ingrowth can be accomplished, whereas with increasing pore size up to $157 \mu \mathrm{m}$, the undesired inflammatory FBGC reaction could be diminished and capillary sprouting was allowed from the outside in a Chacma baboon model. However, before its completion, transmural ingrowth slowed down when reaching the dense inner fibrin layer that was "squeezed" into the pores from the inside (Zilla et al. 2007).

Although PU grafts possess many interesting features, e.g. the presence of EC under poor hemodynamic conditions, excellent healing, good surgical handling and low suture bleeding (Tiwari et al. 2002), further investigations are required before more recommendations can be made, because there is a lack of evidence for their use in human peripheral bypass surgery (Dereume et al. 1993). An outline of synthetic vascular prostheses is summarized in Table 3.

\section{Vascular grafts with modified lumen}

Several attempts have been adopted to suppress the thrombogenicity of synthetic material by affixing chemicals or anticoagulants to the graft lumen: early studies showed decreased platelet deposition on carboncoated ePTFE grafts, but the overall patency rates were not improved (Kapfer et al. 2006). A heparin-bonded Dacron graft exhibited slightly better patency than an untreated ePTFE graft (Devine et al. 2004), and heparinimmobilized ePTFE provided better thromboresistance in humans (Bosiers et al. 2006). Applying a polyethylene glycol (PEG)-hirudin/iloprost coating to $4 \mathrm{~mm}$ ePTFE prostheses reduced $\mathrm{IH}$ and led to superior patency in a pig experiment (Heise et al. 2006). Heparin coating significantly reduced aortic graft thrombosis in rats both for ePTFE and for PU (Walpoth et al. 1998). A dipyridamole (anti-platelet drug) coating positively influenced the patency rate of a $5 \mathrm{~mm}$ PU vascular prosthesis in animal experiments (Aldenhoff et al. 2001). Fibroblast growth factor-1 and heparin affixation enhanced ePTFE graft capillarization and surface endothelialization without significant IH in a canine aorta model (Gray et al. 1994). Antithrombotic agents are of course routinely administered to patients with vascular disease, with an obvious influence on graft patency and overall cardiovascular mortality (Watson et al. 1999).

Interestingly, an effort has been made to increase the resistance of synthetic vascular grafts to infectious 
Table 3. Synthetic vascular grafts in clinical use.

\begin{tabular}{|c|c|c|c|c|c|c|}
\hline & \multicolumn{6}{|c|}{ Synthetic vascular grafts } \\
\hline & \multicolumn{2}{|c|}{ PET (Dacron, Terylen) } & \multicolumn{2}{|c|}{ ePTFE (Teflon, Gore-Tex) } & \multicolumn{2}{|c|}{ Polyurethane } \\
\hline & Woven & Knitted & $\begin{array}{l}\text { Low-porosity } \\
(<30 \mu \mathrm{m} \text { IND) }\end{array}$ & $\begin{array}{l}\text { High-porosity } \\
(>45 \mu \mathrm{m} \text { IND) }\end{array}$ & Fibrillar & Foamy \\
\hline Advantages & $\begin{array}{l}\text { Better stability, } \\
\text { lower } \\
\text { permeability and } \\
\text { less bleeding }\end{array}$ & $\begin{array}{l}\text { Greater porosity, } \\
\text { tissue ingrowth and } \\
\text { radial distensibility }\end{array}$ & $\begin{array}{l}\text { Biostability, no } \\
\text { dilation over time }\end{array}$ & $\begin{array}{l}\text { Biostability, better cell } \\
\text { ingrowth }\end{array}$ & \multicolumn{2}{|c|}{$\begin{array}{l}\text { Compliance, good hemo- } \\
\text { and biocompatibility, less } \\
\text { thrombogenicity }\end{array}$} \\
\hline Disadvantages & $\begin{array}{l}\text { Reduced } \\
\text { compliance and } \\
\text { tissue } \\
\text { incorporation, } \\
\text { low porosity, } \\
\text { fraying at edges, } \\
\text { infection risk }\end{array}$ & $\begin{array}{l}\text { Dilation over time, } \\
\text { infection risk }\end{array}$ & $\begin{array}{l}\text { Stitch bleeding, } \\
\text { limited } \\
\text { incorporation, } \\
\text { infection risk, } \\
\text { perigraft seroma } \\
\text { formation }\end{array}$ & $\begin{array}{l}\text { Late neointimal } \\
\text { desquamation in } 90 \\
\mu \mathrm{m} \text { IND, infection risk }\end{array}$ & \multicolumn{2}{|c|}{$\begin{array}{l}\text { Biodegradation in first } \\
\text { generation, infection risk, } \\
\text { carcinogenic? }\end{array}$} \\
\hline Healing & $\begin{array}{l}\text { Inner fibrinous } \\
\text { capsule, outer } \\
\text { collagenous } \\
\text { capsule, scarce } \\
\text { endothelial } \\
\text { islands }\end{array}$ & $\begin{array}{l}\text { Fibrin luminal } \\
\text { coverage, very } \\
\text { sporadic } \\
\text { endothelium, } \\
\text { transanastomotic } \\
\text { endothelialization } \\
\text { in animals }\end{array}$ & $\begin{array}{l}\text { Luminal fibrin and } \\
\text { platelet carpet, } \\
\text { connective tissue } \\
\text { capsule with } \\
\text { foreign body giant } \\
\text { cells, no transmural } \\
\text { tissue ingrowth }\end{array}$ & $\begin{array}{l}\text { Macrophages and } \\
\text { polymorphonuclear } \\
\text { invasion, capillary } \\
\text { sprouting, fibroblast } \\
\text { migration, certain } \\
\text { angiogenesis, thicker } \\
\text { neointima, } \\
\text { endothelialization in } \\
\text { animals }\end{array}$ & $\begin{array}{l}\text { Thin inner } \\
\text { fibrin layer, } \\
\text { outside } \\
\text { foreign body } \\
\text { cells, limited } \\
\text { ingrowth }\end{array}$ & $\begin{array}{l}\text { Better } \\
\text { ingrowth } \\
\text { with } \\
\text { bigger } \\
\text { pores }\end{array}$ \\
\hline First use & \multicolumn{2}{|l|}{ Ku et al. 1957} & \multicolumn{2}{|c|}{ Norton and Eiseman 1975} & \multicolumn{2}{|c|}{ Boretos and Pierce 1967} \\
\hline Reviewe.g. & \multicolumn{2}{|c|}{ Xue and Greisler 2003} & \multicolumn{2}{|l|}{ Nishibe et al. 2004} & \multicolumn{2}{|c|}{ Tiwari et al. 2002} \\
\hline
\end{tabular}

IND (internodal distance).

agents. Antibiotics such as rifampicin bonded to Dacron did not reduce the incidence of vascular graft infection (Earnshaw et al. 2000); however, a silver-coated collagen-impregnated Dacron prosthesis offers an alternative approach in the treatment of vascular graft infection (Mirzaie et al. 2007).

\section{Composite and vein-interposition vascular grafts}

Attempts at improving disadvantageous anastomotic hemodynamics include alternative surgical techniques and interposition of an autologous vein segment.

Despite the theoretical and experimental advantage of end-to-end (straight) rather than end-to-side (Y-shaped) anastomosis between the graft and the artery (O'Brien et al. 2007), clinical trials did not prove superiority, and moreover an increased limb amputation rate was revealed in the end-to-end setting, probably due to exclusion of collateral vessels (Schouten et al. 2005). Suturing materials and techniques may also decrease the anastomotic compliance difference, e.g. in the case of interrupted sutures (more than one single suture).
However, running sutures are most widely used, because they are quicker and achieve better hemostasis (Tiwari et al. 2003).

Own venous tissue is placed in the form of a vein patch or cuff between an ePTFE graft and the artery to reduce the anastomotic compliance mismatch and to improve the prosthesis patency. Procedures implemented during the 1980s and 1990s include the Miller cuff, the Linton patch, the Taylor patch and the St. Mary boot (Moawad and Gagne 2003). When the patient's own vein graft is of insufficient length, feasible options that increase the patency rates may be: a composite bypass prosthesis and vein are spliced together with an additional anastomosis (Bastounis et al. 1999), a sequential bypass, which is formed as a distal venous extension graft to the preceding proximal prosthetic bypass (Mahmood et al. 2002), and a bridge graft, which connects two patent distal arteries with a short vein segment (Deutsch et al. 2001). Although adjunctive arterio-venous fistula placement increases the blood flow through femoro-distal (i.e. below knee) bypasses, thus theoretically preventing thrombosis, several trials failed to show evidence of 
benefit (Laurila et al. 2006).

Vein interposition techniques are generally useful in the case of distal anastomosis located below the knee, but are unimportant in the above-the-knee position (Mamode and Scott 2000). The underlying mechanism consists in reducing the compliance mismatch and suppressing IH (Cabrera Fischer et al. 2005). Research derived from this evidence led to the evolution of specially formed ePTFE grafts, capable of better harnessing the hemodynamic forces by an enlarged anastomotic hood. Interestingly, clinical studies have shown patency rates of this pre-cuffed ePTFE (Panneton et al. 2004) and carbon-lined ePTFE Distaflo graft (Fisher et al. 2003) that are comparable to interposition vein cuffs.

\section{Biosynthetic/biohybrid vascular grafts (biografts)}

The idea of introducing viable biological components into an artificial material-based vascular graft was established to produce more biocompatible vascular substitutes. A viable endothelial layer is the best antithrombogenic surface. There are three possible sources of graft lumen endothelialization in vivo post implantation: trans-anastomotic ingrowth from the native artery, transmural tissue and capillary ingrowth through the prosthesis wall, and a "fall-out" or blood-borne source from circulating progenitor cells. Unlike animals, humans seldom achieve spontaneous endothelialization more than 1-2 $\mathrm{cm}$ from an anastomosis, and transmural ingrowth is hampered by the structure of currently-used prostheses (Zilla et al. 2007).

The concept of seeding endothelial cells onto the graft lumen before implantation was experimentally implemented (Herring et al. 1978), and consequently this autologous EC “transplantation" managed to improve the patency of human Dacron prostheses (Herring et al. 1984) in a non-smoker population. Endothelial cells from a subcutaneous vein segment (e.g. saphenous, cephalic or jugular vein) are harvested and immediately seeded onto the graft lumen within the timeframe of one operation. The results of the first clinical trials performed during the 1980s were controversial and disappointing, mainly due to insufficient cell density (Bordenave et al. 1999). However, sophisticated EC extraction and retention techniques (Tiwari et al. 2001) and the search for more abundant cell sources, such as microvascular endothelium from fat tissue or an omentum biopsy, improved the outcome of this single-stage cell seeding method (Alobaid et al. 2005).
On the other hand, the double-stage approach involves a prolonged incubation and cell multiplication period (2-4 weeks) between cell harvesting and implantation (Bordenave et al. 2005). Nevertheless, in vitro flow pretreatment or shear stress preconditioning of the cell-material constructs before exposing them to arterial conditions enhances cell retention by inducing structural changes and adaptation (Rademacher et al. 2001). This means that an endothelial cell monolayer is physiologically exposed to certain mechanical forces, namely hydrostatic pressure resulting from blood pressure, shear stress resulting from tangential friction of blood flow against the vessel wall, and finally longitudinal and circumferential cyclic stretch resulting from repeated blood vessel distension due to the cardiac cycle (Lehoux et al. 2006). Chronic laminar versus turbulent shear stress seems to be of utmost importance for endothelial and vascular smooth muscle cell function (Chien 2007), regulating signal transduction in these cells (Daculsi et al. 2007), their alignment, molecule secretion, cytoskeleton reorganization, gene expression, cell migration, proliferation and survival. These processes ultimately influence thrombogenesis and atherogenesis (Yoshizumi et al. 2003), and similar cellular events and phenotypes (Rémy-Zolghadri et al. 2004, Fernandez et al. 2006) can be observed when cells are seeded on biomaterials (Fernandez et al. 2007).

Early results of clinical in vitro double-stage endothelialization were promising (Magometschnigg et al. 1992, Meinhart et al. 1997), and recently published overall 5-year and 10-year patency of endothelialized fibrin glue-precoated ePTFE femoro-popliteal bypass grafts of $69 \%$ and $61 \%$, respectively (Deutsch et al. 2009) has already been correctly reported to close the gap between prosthetic and vein grafts (Meinhart et al. 1997). Interestingly, the feasibility of endothelium-seeded vascular prostheses was also confirmed in coronary bypass grafting, though it is not widely used (Laube et al. 2000).

To improve the above-mentioned clinical success, additional cell sources and cell retention technologies are being investigated. Vascular cells are anchorage-dependent, and integrin receptor-mediated adhesion occurs via ECM proteins that are adsorbed from the cell culture media in vitro or from blood in vivo (Bačáková et al. 2004). Thus, to regulate cell attachment, biomaterials are coated with ECM proteins such as collagen, laminin and fibronectin (Vara et al. 2005) or are modified by covalent bonding of short adhesive peptides 
which may be cell specific, such as the Arg-Gly-Asp (RGD) sequence (Bačáková et al. 2007). Fibrin, as a natural scaffold for cell migration and healing, plays a pivotal role in tissue engineering of vascular grafts (Filová et al. 2009). In addition, less specific physical surface modifications, non-ligand based techniques (Salacinski et al. 2001) and surface nanoarchitecturing (de Mel et al. 2008) are being explored.

An alternative approach aimed at improving seeding efficiency is to use progenitor cells. Bone marrow cells infiltrated into the ePTFE vascular grafts and implanted in the aortic position of dogs retained complete endothelialization and patency after six months (Noishiki et al. 1996). Similarly, human endothelial progenitor cells (EPC) were isolated from peripheral blood (Asahara et al. 1997), and it has been shown in a canine model that a subset of CD34+ bone marrow cells can be mobilized to the circulation and can colonize the flow surfaces of Dacron vascular prostheses (Shi et al. 1998). Moreover, seeding of bone marrow-derived cells (BMC) accelerated early Dacron graft endothelialization without increasing thrombogenicity in a dog model (Bhattacharya et al. 2000). Taken together, due to their high proliferative capacity and differentiation potential, stem cells may represent the next era of cell-sourcing technology (Riha et al. 2005).

Genetically-modified cells have also been considered for the construction of vascular replacements. For example, genetically-modified endothelial cells overexpressing tissue plasminogen activator (t-PA) and urokinase-type PA, or bone marrow mesenchymal stem cells transduced to express endothelial nitric oxide synthase (eNOS), would promote cell repopulation of the graft and help to eliminate thrombotic events (Zarbiv et al. 2007). However, the use of genetically-modified cells inherently raises ethical questions. A conventional approach is directly to load the materials with anticoagulant, anti-inflammatory and cell growth-regulating substances, such as heparin and heparin-like molecules, as mentioned above (Walpoth et al. 1998, Lee et al. 2002), hirudin (Heise et al. 2006), dipyridamole (Aldenhoff et al. 2001), growth factors, such as vascular endothelial growth factor (Ehrbar et al. 2005) or fibroblast growth factor (Gray et al. 1994, Sato et al. 2008), or antimigratory and antiproliferative drugs paclitaxel (Lim et al. 2007), sirolimus (Ishii et al. 2008) and inhibitors of CDK2 kinase (Brooks et al. 1997). These drugs can be incorporated directly into the prosthesis wall or delivered through drug-eluting stents
(Lee et al. 2008), catheters and perivascular collars (for review see Sriram and Patterson 2001). Artificial materials releasing NO are also being developed, consisting of synthetic polymers (e.g. polyurethane, PTFE) incorporated with NO donors, such as diazeniumdiolates and S-nitrosothiols (Varu et al. 2009).

Living vascular grafts, totally-engineered blood vessels (TEBV)

The concept of completely biological living grafts implies the ability to remodel, grow, self-repair and respond to the immediate environment. Similarly to the native artery, the graft would consist of a functional endothelial cell layer resting on metabolically active smooth muscle cells which are in a contractile (i.e. nonsynthetic and anti-atherogenic) phenotype (Muto et al. 2007). The graft would also contain enough collagen and elastin proteins to display desirable viscoelastic properties, and would lack any synthetic foreign material that would initiate chronic inflammatory responses or be susceptible to infection. If a synthetic material is used, it should be non-immunogenic, non-thrombogenic and of appropriate compliance. In the ideal case, it should be degradable, providing a temporary scaffold for vascular tissue regeneration, gradually removed and replaced by the newly-forming tissue.

In the construction of tissue-engineered vascular grafts, three major components must be addressed: a scaffold to provide the initial graft shape and strength, adhesive matrix and living vascular cells (Baguneid et al. 2006). For the scaffold, four major approaches can be identified: permanent synthetic support, natural acellular tissues, a biodegradable scaffold, and non-scaffold technology (Campbell and Campbell 2007).

The first seminal attempt involved seeding bovine EC, VSMC and fibroblasts onto collagen gel tubes (Weinberg and Bell 1986). An external Dacron mesh reinforcement had to be added because of poor mechanical strength. An example of the use of a natural scaffold involves seeding human cells on decellularized porcine aorta (Bader et al. 2000) or small intestinal submucosa implanted as vascular grafts (Lantz et al. 1993). The most commonly used biodegradable polymer is polyglycolic acid (PGA). Under shear stress preconditioning, VSMC followed by EC were seeded onto this scaffold, and the resulting vascular grafts were implanted in pigs, with excellent results (Niklason et al. 1999). Seeding bone-marrow cells (BMC) onto a biodegradable scaffold enabled the establishment of a 
Table 4. Composite, biosynthetic and totally engineered vascular grafts in experimental and clinical use.

\begin{tabular}{|c|c|c|c|c|c|}
\hline & \multirow{2}{*}{$\begin{array}{l}\text { Composite grafts } \\
\text { Clinical }\end{array}$} & \multicolumn{2}{|c|}{ Biosynthetic grafts } & \multicolumn{2}{|c|}{ Totally engineered blood vessels } \\
\hline & & Experimental & Clinical & Experimental & Clinical \\
\hline Advantages & $\begin{array}{l}\text { Reduced compliance } \\
\text { mismatch and intimal } \\
\text { hyperplasia, improved } \\
\text { patency in femoro-distal } \\
\text { bypasses, easier redo } \\
\text { surgery }\end{array}$ & \multicolumn{2}{|c|}{ Antithrombogenic, better patency } & \multicolumn{2}{|c|}{$\begin{array}{l}\text { Responsiveness, non-thrombogenicity, self- } \\
\text { repair, growth, metabolically active, } \\
\text { potentially cost-effective }\end{array}$} \\
\hline Disadvantages & $\begin{array}{l}\text { Technically demanding, } \\
\text { prolonged surgery time }\end{array}$ & \multicolumn{2}{|c|}{$\begin{array}{l}\text { No emergency use, cell amplification } \\
\text { problems, cell culture contamination risk }\end{array}$} & \multicolumn{2}{|c|}{$\begin{array}{l}\text { Demanding fabrication, time- and cost- } \\
\text { consuming, bioreactor cell laboratory, } \\
\text { specialized centers only }\end{array}$} \\
\hline Healing & Less intimal hyperplasia & \multicolumn{2}{|c|}{ Self-renewing functional endothelium } & \multicolumn{2}{|l|}{ Complete integration } \\
\hline First use & Siegman 1979 & Herring et al. 1978 & Herring et al. 1984 & $\begin{array}{l}\text { Weinberg and Bell } \\
1986\end{array}$ & Shin'oka et al. 2001 \\
\hline Reviewe.g. & Moawad and Gagne 2003 & Seifalian et al. 2002 & $\begin{array}{l}\text { Bordenave et al. } \\
2008\end{array}$ & $\begin{array}{l}\text { Isenberg et al. } \\
2006\end{array}$ & $\begin{array}{l}\text { L'Heureux et al. } \\
\text { 2007a }\end{array}$ \\
\hline
\end{tabular}

totally-engineered autograft implanted into the inferior vena cava of a dog, and explant analysis showed that $\mathrm{BMC}$ were able to differentiate both in endothelial and smooth muscle cells (Matsumura et al. 2003).

The non-scaffold or "self-assembly" approach produced a graft composed exclusively of human cells by wrapping and culturing fibroblast and VSMC cellular sheets on a PTFE mandril, which was then removed and EC were seeded in the lumen. This was the first completely biological TEBV to display mechanical resistance comparable to that of human vessels (experimental burst strength up to $2000 \mathrm{~mm} \mathrm{Hg}$ ). A shortterm experiment in a canine model demonstrated good surgical handling (L'Hereux et al. 1998). Another vascular graft was developed without a scaffold by inducing an inflammatory reaction. A silastic tube was placed into the peritoneal cavity of rats and rabbits and was in 2 weeks spontaneously covered by layers of myofibroblasts, collagen matrix, and a single layer of mesothelium. It was everted to resemble the blood vessel and grafted in carotid or aortic position, and remained patent after 4 months (Campbell et al 1999).

A TEBV construct consisting of autologous bone marrow cells seeded onto a biodegradable scaffold was first clinically implanted to replace the pulmonary artery in a pediatric patient with a cyanotic defect (Shin'oka et al. 2001), and there was no graft-related complication in a group of 42 patients (Shin'oka et al. 2005). Another clinical success was achieved by TEBV produced by the cell-sheet multilayer method (L'Heureux et al. 2006) and implanted as a hemodialysis access graft in 10 patients (L'Heureux et al. 2007b). A recent paper reports primary 1-month and 6-month patency of $78 \%$ and $60 \%$, respectively, meeting the approved criteria for a high-risk patient cohort (McAlister et al. 2009).

A summary of composite, biohybrid and totallyengineered vascular grafts is outlined in Table 4.

\section{Venous replacements}

Unlike arterial reconstructions, venous reconstructions are limited to large-diameter central veins, such as the inferior (Schwarzbach et al. 2006) or superior vena cava and the ilico-femoral veins (Kalra et al. 2003). Autologous size- and length-matched veins such as superficial femoral vein, internal jugural vein, left renal vein and mainly the gold-standard composite saphenous spiral vein graft (Doty et al. 1999) produce the best results, e.g. for a bypass for an occlusion of the superior vena cava of iatrogenic origin (catheter-related thrombosis). Venous allogenous homografts, either fresh or cryopreserved, have been used in experimental and clinical venous reconstruction (Sitzmann et al. 1984). The patency of externally supported ePTFE is better than the patency of grafts fashioned from ePTFE alone. However, the use of synthetic prostheses may be limited by lowflow thrombogenicity, contaminated tissue beds, as in venous vascular trauma or tumor resection cases, e.g. in portal vein resection for pancreatic carcinoma (Leon et al. 2007). Venous reconstructions may be combined with an 

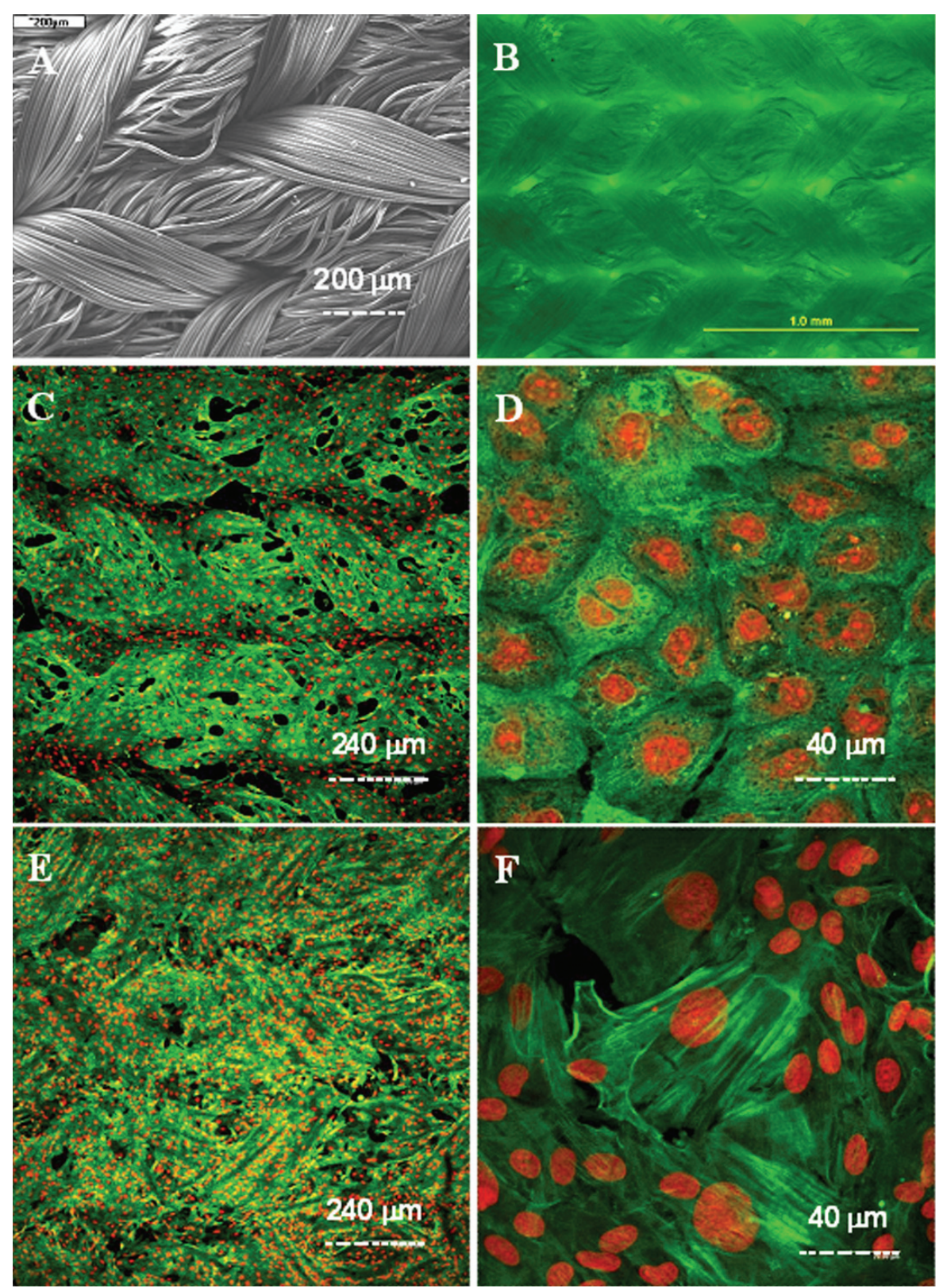

Fig. 3. Innovation of knitted PET vascular prostheses produced by VUP a.s., Brno, Czech Republic. A: the rough and highly hydrophobic inner surface of the prosthesis not suitable for cell adhesion; B: coating of this surface with defined molecular assemblies such as collagen I (Co), laminin (LM), fibronectin (FN) or fibrin $(\mathrm{Fb})$ makes it more adhesive; C, D, E, $\mathbf{F}$ : confluent layer of bovine vascular endothelial cells (line CPAE) on CoFb $(C, D)$ and multilayer of rat aortic smooth muscle cells on CoFN (E), CoLM (F) on the inner surface of a knitted wrapped prosthesis. Immunofluorescence of beta-actin ( $C, D)$ or alphaactin $(E, F)$, nuclei counterstained with propidium iodide. NOVA nanoSEM 200 FEI electron microscope (A), Olympus IX 51 fluorescence $t$ microscope, obj. 4x (B) or Leica TCS SP2 AOBS confocal microscope, obj. 10x, 29x5 $\mu \mathrm{m}$ (C), 40x, zoom 2x, 4x1 $\mu \mathrm{m}$ (D), obj. 10x, $9 \times 15 \mu \mathrm{m}(\mathrm{E}), 40 \mathrm{x}$, zoom 2x, 55x1 $\mu \mathrm{m}$ (F). adjuvant arterio-venous fistula to improve graft patency. Interestingly, the success rates of repeated percutaneous angioplasty approached those of operative reconstruction (Wisselink et al. 1993).

\section{Hemodialysis vascular access}

Creating a native arterio-venous fistula for chronic hemodialysis access is obviously superior to creating a prosthetic fistula. However, patients with depleted veins receive a prosthetic access graft, which has to provide sufficient blood flow and sustain repeated puncturing. It is difficult to identify the ideal access graft from a large number of biologic and prosthetic conduits. Randomized trials suggest that cuffed ePTFE grafts offer reasonable patency and that "early access" PU grafts can provide a safe conduit. Biologic/semibiologic grafts give better results than synthetic grafts, in some respects (Scott and Glickman 2007).

\section{Collective experience of the authors}

Static experiments performed in our laboratory enabled us to assess the cell colonization of various biomaterials without flow of culture medium. Clinicallyused PET vascular prostheses (produced by VÚP, Brno, Czech Republic) were impregnated with biodegradable polyester-based copolymers (Pamula et al. 2008) as a background for further modification with multilayers of adhesive matrix proteins, such as collagen, fibronectin, 
laminin and particularly fibrin, which can be derived in autologous form from the patient's blood (Brynda et al. 2005, Filová et al. 2009). For the purposes of vascular tissue engineering, we explored the adhesion and growth of animal-derived endothelial and vascular smooth muscle cells (Chlupáč et al. 2008a) (Fig. 3). Research work carried out on some fibrin-based surfaces (Riedel et al. 2009) has led to a common patent (Brynda et al. 2008).

Dynamic experiments were conducted under defined medium flow to better mimic in vivo conditions. Dacron vascular prostheses were modified on the luminal surface with ECM protein assemblies (Chlupáč et al. 2006a), and an investigation was made of the adhesion and growth of human patient-derived EC (Chlupáč et al. 2006b). Their resistance to shear stress was also investigated (Chlupáč et al. 2006c). The gene expression profile of endothelium seeded on similar planar ECM analogues was also determined (Chlupáč et al. 2008b). Hybrid vascular graft constructs in vitro seeded with autologous EC and preconditioned under shear stress in a bioreactor (Provitro Co., Berlin Germany) are currently being investigated in a porcine model.

\section{Conclusions}

Open arterial surgery in the form of a lower limb bypass remains the standard treatment for extensive and multilevel atherosclerotic disease. Over the past 50 years, no synthetic alternative has been found to compare with the patency rates of gold-standard autologous conduits. However, appropriate native material is often unavailable and alternative vascular prostheses show poor clinical performance. To address this issue, luminal modifications of grafts, interposition of vein segments and particularly tissue engineering of small-sized blood vessels have been introduced. Biohybrid and tissue-engineered vascular grafts have been manufactured with the help of materials research, complex tissue culture and cell seeding technologies. The outcomes of experimental and clinical implants seem to be favorable. It is likely that cell therapy will become a frequent option in vascular and endovascular surgery in the coming decades.

\section{Conflict of Interest}

There is no conflict of interest.

\section{Acknowledgements}

This study was supported by the Centre for Cardiovascular Research (grant No. 1M6798582302 provided by the Ministry of Education, Youth and Sports of the Czech Republic) and by the Academy of Sciences of the Czech Republic (grant No. 1QS500110564). Mr. Robin Healey (Czech Technical University, Prague) is gratefully acknowledged for his language revision of the manuscript. We also thank Mrs. Jana Voborníková for her excellent technical assistance in preparing the manuscript.

\section{References}

ALOBAID N, SALACINSKI HJ, SALES KM, HAMILTON G, SEIFALIAN AM: Single stage cell seeding of small diameter prosthetic cardiovascular grafts. Clin Hemorheol Microcirc 33: 209-226, 2005.

ALDENHOFF YB, VAN DER VEEN FH, TER WOORST J, HABETS J, POOLE-WARREN LA, KOOLE LH: Performance of a polyurethane vascular prosthesis carrying a dipyridamole (Persantin) coating on its lumenal surface. J Biomed Mater Res 54: 224-233, 2001.

ALI AT, MODRALL JG, HOCKING J, VALENTINE RJ, SPENCER H, EIDT JF, CLAGETT GP: Long-term results of the treatment of aortic graft infection by in situ replacement with femoral popliteal vein grafts. J Vasc Surg 50: 30-39, 2009.

ASAHARA T, MUROHARA T, SULLIVAN A, SILVER M, VAN DER ZEE R, LI T, WITZENBICHLER B, SCHATTEMAN G, ISNER JM: Isolation of putative progenitor endothelial cells for angiogenesis. Science 275: 964-967, 1997.

BAČÁKOVÁ L, FILOVÁ E, RYPÁČEK F, ŠVORČÍK V, STARÝ V: Cell adhesion on artificial materials for tissue engineering. Physiol Res 53 (Suppl 1): S35-S45, 2004.

BAČÁKOVÁ L, FILOVÁ E, KUBIES D, MACHOVÁ L, PROKS V, MALINOVÁ V, LISÁ V, RYPÁČEK F: Adhesion and growth of vascular smooth muscle cells in cultures on bioactive RGD peptide-carrying polylactides. J Mater Sci Mater Med 18: 1317-1323, 2007. 
BADER A, STEINHOFF G, STROBL K, SCHILLING T, BRANDES G, MERTSCHING H, TSIKAS D, FROELICH J, HAVERICH A: Engineering of human vascular aortic tissue based on a xenogeneic starter matrix. Transplantation 70: 7-14, 2000.

BAGUNEID MS, SEIFALIAN AM, SALACINSKI HJ, MURRAY D, HAMILTON G, WALKER MG: Tissue engineering of blood vessels. Br J Surg 93: 282-290, 2006.

BASTOUNIS E, GEORGOPOULOS S, MALTEZOS C, ALEXIOU D, CHIOTOPOULOS D, BRAMIS J: PTFE-vein composite grafts for critical limb ischaemia: a valuable alternative to all-autogenous infrageniculate reconstructions. Eur J Vasc Endovasc Surg 18: 127-132, 1999.

BEGHI C, NICOLINI F, BUDILLON AM, BORRELLO B, BALLORE L, REVERBERI C, GHERLI T.: Midterm clinical results in myocardial revascularization using the radial artery. Chest 122: 2075-2079, 2002.

BERGER K, SAUVAGE L, RAO A, WOOD S: Healing of arterial prostheses in man: its incompleteness. Ann Surg 175: 118-127, 1972.

BHATTACHARYA V, MCSWEENEY PA, SHI Q, BRUNO B, ISHIDA A, NASH R, STORB RF, SAUVAGE LR, HAMMOND WP, WU MH: Enhanced endothelialization and microvessel formation in polyester grafts seeded with CD34 ${ }^{+}$bone marrow cells. Blood 95: 581-585, 2000.

BLAKEMORE AH, VOORHEES AB Jr: The use of tubes constructed from vinyon $\mathrm{N}$ cloth in bridging arterial defects; experimental and clinical. Ann Surg 140: 324-334, 1954.

BLUMENBERG RM, GELFAND ML, BARTON EA, BOWERS CA, GITTLEMAN DA: Clinical significance of aortic graft dilation. J Vasc Surg 14: 175-180, 1991.

BORDENAVE L, RÉMY-ZOLGHADRI M, FERNANDEZ P, BAREILLE R, MIDY D: Clinical performance of vascular grafts lined with endothelial cells. Endothelium 6: 267-275, 1999.

BORDENAVE L, FERNANDEZ P, RÉMY-ZOLGHADRI M, VILLARS S, DACULSI R, MIDY D: In vitro endothelialized ePTFE prostheses: clinical update 20 years after the first realization. Clin Hemorheol Microcirc 33: 227-234, 2005.

BORDENAVE L, MENU P, BAQUEY C: Developments towards tissue-engineered, small-diameter arterial substitutes. Expert Rev Med Devices 5: 337-347, 2008.

BORETOS JW, PIERCE WS: Segmented polyurethane: a new elastomer for biomedical applications. Science 158: 1481-1482, 1967.

BOSIERS M, DELOOSE K, VERBIST J, SCHROË H, LAUWERS G, LANSINK W, PEETERS P: Heparin-bonded expanded polytetrafluoroethylene vascular graft for femoropopliteal and femorocrural bypass grafting: 1-year results. J Vasc Surg 43: 313-319, 2006.

BREWSTER DC: Current controversies in the management of aortoiliac occlusive disease. J Vasc Surg 25: 365-379, 1997.

BROOKS EE, GRAY NS, JOLY A, KERWAR SS, LUM R, MACKMAN RL, NORMAN TC, ROSETE J, ROWE M, SCHOW SR, SCHULTZ PG, WANG X, WICK MM, SHIFFMAN D: CVT-313, a specific and potent inhibitor of CDK2 that prevents neointimal proliferation. J Biol Chem 272: 29207-29211, 1997.

BRYNDA E, PACHERNÍK J, HOUSKA M, PIENTKA Z, DVOŘÁK P: Surface immobilized protein multilayers for cell seeding. Langmuir 21: 7877-7883, 2005.

BRYNDA E, RIEDEL T, DYR J, HOUSKA M, BAČÁKOVÁ L, FILOVÁ E, CHLUPÁČ J, LESNÝ P, JENDELOVÁ P, SYKOVÁ E: Mode of preparation of controlled fibrin assemblies on solid surfaces (Způsob prípravy regulovaných vrstev fibrinu na pevných površích), Czech Patent Application, registered in the UPV Office under No. 2006-821, accepted in 2008.

CABRERA FISCHER EI, BIA SANTANA D, CASSANELLO GL, ZÓCALO Y, CRAWFORD EV, CASAS RF, ARMENTANO RL: Reduced elastic mismatch achieved by interposing vein cuff in expanded polytetrafluoroethylene femoral bypass decreases intimal hyperplasia. Artif Organs 29: 122-130, 2005.

CALLIGARO KD, SYREK JR, DOUGHERTY MJ, RUA I, RAVIOLA CA, DELAURENTIS DA: Use of arm and lesser saphenous vein compared with prosthetic grafts for infrapopliteal arterial bypass: are they worth the effort? J Vasc Surg 26: 919-927, 1997.

CAMPBELL JH, EFENDY JL, CAMPBELL GR: Novel vascular graft grown within recipient's own peritoneal cavity. Circ Res 85: 1173-1178, 1999. 
CAMPBELL GR, CAMPBELL JH: Development of tissue engineered vascular grafts. Curr Pharm Biotechnol 8: 43$50,2007$.

CHANG BB, PATY PS, SHAH DM, LEATHER RP: The lesser saphenous vein: an underappreciated source of autogenous vein. J Vasc Surg 15: 152-157, 1992.

CHEMLA ES, MORSY M: Randomized clinical trial comparing decellularized bovine ureter with expanded polytetrafluoroethylene for vascular access. Br J Surg 96: 34-39, 2009.

CHESHIRE NJW, WOLFE MS, NOONE MA, DAVIES L, DRUMMOND M: The economics of femorocrural reconstruction for critical limb ischaemia with and without autologous vein. J Vasc Surg 15: 167-175, 1992.

CHIEN S: Mechanotransduction and endothelial cell homeostasis: the wisdom of the cell. Am J Physiol 292: H1209H1224, 2007.

CHLUPÁČ J, FILOVÁ E, RIEDEL T, BRYNDA E, REMY-ZOLGHADRI M, BAREILLE R, FERNANDEZ P, DACULSI R, BORDENAVE L, BAČÁKOVÁ L: Human endothelium on vascular prostheses modified by extracellular matrix proteins in a flow experiment. Eng Biomater 58-60: 10-13, $2006 \mathrm{a}$.

CHLUPÁČ J, FILOVÁ E, RIEDEL T, BRYNDA E, REMY-ZOLGHADRI M, BAREILLE R, FERNANDEZ P, DACULSI R, BORDENAVE L, BAČÁKOVÁ L: Innovation of clinically used vascular prostheses by protein assemblies on their luminal surface. Physiol Res 55: 24P, $2006 \mathrm{~b}$.

CHLUPÁČ J, FILOVÁ E, RIEDEL T, BRYNDA E, RÉMY-ZOLGHADRI M, BAREILLE R, FERNANDEZ P, DACULSI R, BORDENAVE L, BAČÁKOVÁ L: Endothelial cells seeded on protein-coated vascular prostheses under experimental shear stress conditions. Atherosclerosis Suppl 7: 159, 2006c.

CHLUPÁČ J, FILOVÁ E, RIEDEL T, BRYNDA E, PAMULA E, LISÁ V, BAČÁKOVÁ L: Endothelial cells on PET vascular prostheses impregnated with polyester-based copolymers and coated with cell-adhesive protein assemblies. Eng Biomater 81-84: 108-111, 2008a.

CHLUPÁČ J, FILOVÁ E, RIEDEL T, BRYNDA E, RÉMY-ZOLGHADRI M, BAREILLE R, FERNANDEZ P, DACULSI R, BORDENAVE L, BAČÁKOVÁ L: Endothelial cells seeded on protein multilayer assemblies under shear stress. Physiol Res 57: 77P, 2008b.

CLOWES AW, ZACHARIAS RK, KIRKMAN TR: Early endothelial coverage of synthetic arterial grafts: porosity revisited. Am J Surg 153: 501-504, 1987.

CONTE MS: The ideal small arterial substitute: a search for the Holy Grail? FASEB J 12: 43-45, 1998.

COOPER GJ, UNDERWOOD MJ, DEVERALL PB: Arterial and venous conduits for coronary artery bypass. A current review. Eur J Cardiothorac Surg 10: 129-140, 1996.

DACULSI R, RÉMY-ZOLGHADRI M, GRELLIER M, CONRAD V, FERNANDEZ P, BAREILLE R, BORDENAVE L: Signal transduction and procoagulant state of human cord blood-progenitor-derived endothelial cells after interleukin-1alpha stimulation. Endothelium 14: 163-171, 2007.

DAHL SL, KOH J, PRABHAKAR V, NIKLASON LE: Decellularized native and engineered arterial scaffolds for transplantation. Cell Transplant 12: 659-666, 2003.

DARDIK H, WENGERTER K, QIN F, PANGILINAN A, SILVESTRI F, WOLODIGER F, KAHN M, SUSSMAN B, IBRAHIM IM: Comparative decades of experience with glutaraldehyde-tanned human umbilical cord vein graft for lower limb revascularization: an analysis of 1275 cases. J Vasc Surg 35: 64-71, 2002.

DE MEL A, BOLVIN C, EDIRISINGHE M, HAMILTON G, SEIFALIAN AM: Development of cardiovascular bypass grafts: endothelialization and applications of nanotechnology. Expert Rev Cardiovasc Ther 6: 1259-1277, 2008.

De MOL VAN OTTERLOO JC, VAN BOCKEL JH, PONFOORT ED, BRIET E, BROMMER EJ, HERMANS J, DAHA MR: Systemic effects of collagen-impregnated aortoiliac Dacron vascular prostheses on platelet activation and fibrin formation. J Vasc Surg 14: 59-66, 1991.

DEREUME JP, VAN ROMPHEY A, VINCENT G, ENGELMANN E: Femoropopliteal bypass with a compliant, composite polyurethane/Dacron graft: short-term results of a multicentre trial. Cardiovasc Surg 1: 499-503, 1993.

DEUTSCH M, MEINHART J, HOWANIETZ N, FRÖSCHL A, HEINE B, MOIDL R, MENDEL H, SISEL A, STÜMPFLEN A, ZILLA P: The bridge graft: a new concept for infrapopliteal surgery. Eur J Vasc Endovasc Surg 21: 508-512, 2001. 
DEUTSCH M, MEINHART J, ZILLA P, HOWANIETZ N, GORLITZER M, FROESCHL A, STUEMPFLEN A, BEZUIDENHOUT D, GRABENWOEGER M: Long-term experience in autologous in vitro endothelialization of infrainguinal ePTFE grafts. $J$ Vasc Surg 49: 352-362, 2009.

DEVINE C, MCCOLLUM C, THE NORTH WEST FEMOROPOPLITEAL TRIAL PARTICIPANTS: Heparinbonded Dacron and polytetrafuoroethylene for femoforopoplileal bypass: five years results of a perspective randomized multi-centre clinical trial. J Vasc Surg 40: 924-931, 2004.

DOTY JR, FLORES JH, DOTY DB: Superior vena cava obstruction: bypass using spiral vein graft. Ann Thorac Surg 67: 1111-1116, 1999.

EARNSHAW JJ, WHITMAN B, HEATHER BP: Two-year results of a randomized controlled trial of rifampicinbonded extra-anatomic dacron grafts. Br J Surg 87: 758-759, 2000.

EHRBAR M, METTERS A, ZAMMARETTI P, HUBBELL JA, ZISCH AH: Endothelial cell proliferation and progenitor maturation by fibrin-bound VEGF variants with differential susceptibilities to local cellular activity. J Control Release 101: 93-109, 2005.

EMRECAN B, YILIK L, OZBEK C, GÜRBÜZ A: Bovine ureter graft for haemodialysis access surgery. Nephrol Dial Transplant 21: 2290-2291, 2006.

FAHNER PJ, IDU MM, VAN GULIK TM, LEGEMATE DA: Systematic review of preservation methods and clinical outcome of infrainguinal vascular allografts. $J$ Vasc Surg 44: 518-524, 2006.

FARIES PL, LOGERFO FW, ARORA S, PULLING MC, ROHAN DI, AKBARI CM, CAMPBELL DR, GIBBONS GW, POMPOSELLI FB: Arm vein conduit is superior to composite prosthetic-autogenous grafts in lower extremity revascularization. J Vasc Surg 31: 1119-1127, 2000.

FERNANDEZ P, DACULSI R, RÉMY-ZOLGHADRI M, BAREILLE R, BORDENAVE L: Endothelial cells cultured on engineered vascular grafts are able to transduce shear stress. Tissue Eng 12: 1-7, 2006.

FERNANDEZ P, BOURGET C, BAREILLE R, DACULSI R, BORDENAVE L: Gene response in endothelial cells cultured on engineered surfaces is regulated by shear stress. Tissue Eng 13: 1607-1614, 2007.

FILOVÁ E, BRYNDA E, RIEDEL T, BAČÁKOVÁ L, CHLUPÁČ J, LISÁ V, HOUSKA M, DYR JE: Vascular endothelial cells on two-and three-dimensional fibrin assemblies for biomaterial coatings. J Biomed Mater Res A 90: 55-69, 2009.

FISHER RK, KIRKPATRICK UJ, HOW TV, BRENNAN JA, GILLING-SMITH GL, HARRIS PL: The distaflo graft: a valid alternative to interposition vein? Eur J Vasc Endovasc Surg 25: 235-239, 2003.

GLICKMAN MH, STOKES GK, ROSS JR, SCHUMAN ED, STERNBERGH WC, LINDBERG JS, MONEY SM, LORBER MI: Multicenter evaluation of a polytetrafluoroethylene vascular access graft as compared with the expanded polytetrafluoroethylene vascular access graft in hemodialysis applications. J Vasc Surg 34: 465-473, 2001.

GOLDEN MA, HANSON SR, KIRKMAN TR, SCHNEIDER PA, CLOWES AW: Healing of polytetrafluoroethylene arterial grafts is influenced by graft porosity. J Vasc Surg 11: 838-844, 1990.

GOYANNES J: Nuevos trabajos de cirurgia vascular, substituicion plastica de las artérias por las venas o arterioplastia venosa aplicada como nuevo metodo al tratamiento de los aneurysmas. El Siglo Med 53: 446, 1906.

GRAY JL, KANG SS, ZENNI GC, KIM DU, KIM PI, BURGESS WH, DROHAN W, WINKLES JA, HAUDENSCHILD CC, GREISLER HP: FGF-1 affixation stimulates ePTFE endothelialization without intimal hyperplasia. $J$ Surg Res 57: 596-612, 1994.

GROSS RE, HURWITT ES, BILL AH JR, PIERCE EC Jr: Preliminary observations on the use of human arterial grafts in the treatment of certain cardiovascular defects. N Engl J Med 239: 578, 1948.

GUIDOIN R, CHAKFÉ N, MAUREL S, HOW T, BATT M, MAROIS M, GOSSELIN C: Expanded polytetrafluoroethylene arterial prostheses in humans: histopathological study of 298 surgically excised grafts. Biomaterials 14: 678-693, 1993a.

GUIDOIN R, MAUREL S, CHAKFÉ N, HOW T, ZHANG Z, THERRIEN M, FORMICHI M, GOSSELIN C: Expanded polytetrafluoroethylene arterial prostheses in humans: chemical analysis of 79 explanted specimens. Biomaterials 14: 694-704, 1993b. 
GUIDOIN R, MAROIS Y, DENG X, CHAKFÉ N, MAROIS M, ROY R, KING MW, DOUVILLE Y. Can collagen impregnated polyester arterial prostheses be recommended as small diameter blood conduits? ASAIO J 42: 974-983, 1996.

GUYTON RA: Coronary artery bypass is superior to drug-eluting stents in multivessel coronary artery disease. Ann Thorac Surg 81: 1949-1957, 2006.

HARUGUCHI H, TERAOKA S: Intimal hyperplasia and haemodynamic factors in arterial bypass and arteriovenous grafts: a review. J Artif Organs 6: 227-235, 2003.

HEISE M, SCHMIDMAIER G, HUSMANN I, HEIDENHAIN C, SCHMIDT J, NEUHAUS P, SETTMACHER U: PEG-hirudin/iloprost coating of small diameter ePTFE grafts effectively prevents pseudointima and intimal hyperplasia development. Eur J Vasc Endovasc Surg 32: 418-424, 2006.

HERRING M, GARDNER A, GLOVER J: A single-staged technique for seeding vascular grafts with autogenous endothelium. Surgery 84: 498-504, 1978.

HERRING MB, DILLEY R, JERSILD RA JR, BOXER L, GARDNER A, GLOVER J: Seeding arterial prostheses with vascular endothelium. The nature of the lining. Ann Surg 190: 84-90, 1979.

HERRING M, GARDNER A, GLOVER J: Seeding human arterial prostheses with mechanically derived endothelium. The detrimental effect of smoking. J Vasc Surg 1: 279-289, 1984.

HURT AV, BATELLO-CRUZ M, SKIPPER BJ, TEAF SR, STERLING WA Jr: Bovine carotid artery heterografts versus polytetrafluoroethylene grafts. A prospective, randomized study. Am J Surg 146: 844-847, 1983.

ISENBERG BC, WILLIAMS C, TRANQUILLO RT: Small-diameter artificial arteries engineered in vitro. Review. Circ Res 98: 25-35, 2006.

ISHII Y, SAKAMOTO S, KRONENGOLD RT, VIRMANI R, RIVERA EA, GOLDMAN SM, PRECHTEL EJ, HILL JG, DAMIANO RJ Jr: A novel bioengineered small-caliber vascular graft incorporating heparin and sirolimus: excellent 6-month patency. J Thorac Cardiovasc Surg 135: 1237-1245, 2008.

JABOULAY M, BRIAU E: Recherches expérimentelles sur la suture et la greffe artérielles. Lyon Méd 81: 97-99, 1896.

JESCHKE MG, HERMANUTZ V, WOLF SE, KÖVEKER GB: Polyurethane vascular prostheses decreases neointimal formation compared with expanded polytetrafluoroethylene. J Vasc Surg 29: 168-176, 1999.

JOHNSON WC, LEE KK: A comparative evaluation of polytetrafluoroethylene, umbilical vein, and saphenous vein bypass grafts for femoral-popliteal above-knee revascularization: a prospective randomized Department of Veterans Affairs cooperative study. J Vasc Surg 32: 268-277, 2000.

KACHLIK D, BAČA V, STINGL J, SOSNA B, LAMETSCHWANDTNER A, MINNICH B, SETINA M: Architectonic arrangement of the vasa vasorum of the human great saphenous vein. $J$ Vasc Res 44: 157-166, 2007.

KAKISIS JD, LIAPIS CD, BREUER C, SUMPIO BE: Artificial blood vessel: the Holy Grail of peripheral vascular surgery. J Vasc Surg 41: 349-354, 2005.

KALRA M, GLOVICZKI P, ANDREWS JC, CHERRY KJ JR, BOWER TC, PANNETON JM, BJARNASON H, NOEL AA, SCHLECK C, HARMSEN WS, CANTON LG, PAIROLERO PC: Open surgical and endovascular treatment of superior vena cava syndrome caused by nonmalignant disease. J Vasc Surg 38: 215-223, 2003.

KAPFER X, MEICHELBOECK W, GROEGLER FM: Comparison of carbon-impregnated and standard ePTFE prostheses in extra-anatomical anterior tibial artery bypass: a prospective randomized multicenter study. Eur $J$ Vasc Endovasc Surg 32: 155-168, 2006.

KATZMAN HE, GLICKMAN MH, SCHILD AF, FUJITANI RM, LAWSON JH: Multicenter evaluation of the bovine mesenteric vein bioprostheses for hemodialysis access in patients with an earlier failed prosthetic graft. $J \mathrm{Am}$ Coll Surg 201: 223-230, 2005.

KIEFFER E, GOMES D, CHICHE L, FLÉRON MH, KOSKAS F, BAHNINI A: Allograft replacement for infrarenal aortic graft infection: early and late results in 179 patients. J Vasc Surg 39: 1009-1017, 2004.

KLINKERT P, POST PN, BRESLAU PJ, VAN BOCKEL JH: Saphenous vein versus PTFE for above-knee femoropopliteal bypass. A review of the literature. Eur J Vasc Endovasc Surg 27: 357-362, 2004.

KOHLER TR, STRATTON JR, KIRKMAN TR, JOHANSEN KH, ZIERLER BK, CLOWES AW: Conventional versus high-porosity polytetrafluoroethylene grafts: clinical evaluation. Surgery 112: 901-907, 1992. 
LANTZ GC, BADYLAK SF, HILES MC, COFFEY AC, GEDDES LA, KOKINI K, SANDUSKY GE, MORFF RJ: Small intestinal submucosa as a vascular graft: a review. J Invest Surg 6: 297-310, 1993.

LAUBE HR, DUWE J, RUTSCH W, KONERTZ W: Clinical experience with autologous endothelial cell-seeded polytetrafluoroethylene coronary artery bypass grafts. J Thorac Cardiovasc Surg 120: 134-141.

LAURILA K, LUTHER M, ROTH WD, VILKKO P, KANTONEN I, TEITTINEN K, SIHVO EI, IHLBERG L, ALBÄCK A, LEPÄNTALO M: Adjuvant arteriovenous fistula as means of rescue for infrapopliteal venous bypass with poor runoff. $J$ Vasc Surg 44: 985-992, 2006.

LAWSON JA, TANGELDER MJ, ALGRA A, EIKELBOOM BC: The myth of the in situ graft: superiority in infrainguinal bypass surgery? Eur J Vasc Endovasc Surg 18: 149-157, 1999.

LEE HJ, HONG JK, GOO HC, LEE WK, PARK KD, KIM SH, YOO YM, KIM YH: Improved blood compatibility and decreased VSMC proliferation of surface-modified metal grafted with sulfonated PEG or heparin. J Biomater Sci Polym Ed 13: 939-952, 2002.

LEE SW, PARK SW, KIM YH, YUN SC, PARK DW, LEE CW, HONG MK, RHEE KS, CHAE JK, KO JK, PARK JH, LEE JH, CHOI SW, JEONG JO, SEONG IW, CHO YH, LEE NH, KIM JH, CHUN KJ, KIM HS, PARK SJ: A randomized comparison of sirolimus versus paclitaxel-eluting stent implantation in patients with diabetes mellitus. J Am Coll Cardiol 52: 727-733, 2008.

LEHOUX S, CASTIER Y, TEDGUI A: Molecular mechanisms of the vascular responses to haemodynamic forces. J Intern Med 259: 381-392, 2006.

L'HEUREUX N, PÂQUET S, LABBÉ R, GERMAIN L, AUGER FA: A completely biological tissue-engineered human blood vessel. FASEB J 12: 47-56, 1998.

L'HEUREUX N, DUSSERRE N, KONIG G, VICTOR B, KEIRE P, WIGHT TN, CHRONOS NA, KYLES AE, GREGORY CR, HOYT G, ROBBINS RC, MCALLISTER TN: Human tissue-engineered blood vessels for adult arterial revascularization. Nat Med 12: 361-365, 2006.

L'HEUREUX N, DUSSERRE N, MARINI A, GARRIDO S, DE LA FUENTE L, MCALLISTER T: Technology insight: the evolution of tissue-engineered vascular grafts - from research to clinical practice. Nat Clin Pract Cardiovasc Med 4: 389-395, 2007a.

L'HEUREUX N, MCALLISTER TN, DE LA FUENTE LM: Tissue-engineered blood vessel for adult arterial revascularization. $N$ Engl J Med 357: 1451-1453, 2007b.

LEON LR JR, HUGHES JD, PSALMS SB, GUERRA R, BISWAS A, PRASAD A, KROUSE RS: Portomesenteric reconstruction during Whipple procedures: review and report of a case. Vasc Endovascular Surg 41: 537-546, 2007.

LIM HJ, NAM HY, LEE BH, KIM DJ, KO JY, PARK JS: A novel technique for loading of paclitaxel-PLGA nanoparticles onto ePTFE vascular grafts. Biotechnol Prog 23: 693-697, 2007.

LINTON RR: Some practical considerations in the surgery of blood vessel grafts. Surgery 38: 817-834, 1955.

LOPEZ PP, GINZBERG E: Vascular trauma. In: Surgery: Basic Science and Clinical Evidence. JA NORTON, PS BARIE, RR BOLLINGER, AE CHANG, S LOWRY, SJ MULVIHILL, HI PASS, RW THOMPSON (eds), Springer, New York, 2008, pp 521-544.

MAGOMETSCHNIGG H, KADLETZ M, VODRAZKA M, DOCK W, GRIMM M, GRABENWÖGER M, MINAR E, STAUDACHER M, FENZL G, WOLNER E: Clinical study with in vitro endothelial cell lining of expanded polytetrafluoroethylene grafts in crural repeat reconstruction. J Vasc Surg 15: 527-535, 1992.

MAHMOOD A, GARNHAM A, SINTLER M, SMITH SR, VOHRA RK, SIMMS MH: Composite sequential grafts for femorocrural bypass reconstruction: experience with a modified technique. J Vasc Surg 36: 772-778, 2002.

MAMODE N, SCOTT RN: Graft type for femoro-popliteal bypass surgery. Cochrane Database Syst Rev 2: CD001487, 2000.

MAROIS Y, CHAKFÉ N, GUIDOIN R, DUHAMEL RC, ROY R, MAROIS M, KING MW, DOUVILLE Y: An albumin-coated polyester arterial graft: in vivo assessment of biocompatibility and healing characteristics. Biomaterials 17: 3-14, 1996.

MATIA I, JANOUŠEK L, MARADA T, ADAMEC M: Cold-stored venous allografts in the treatment of critical limb ischaemia. Eur J Vasc Endovasc Surg 34: 424-431, 2007. 
MATIA I, ADAMEC M, VARGA M, JANOUŠEK L, LIPAR K, VIKLICKÝ O: Aortoiliac reconstruction with allograft and kidney transplantation as a one-stage procedure: long term results. Eur J Vasc Endovasc Surg 35 : 353-357, 2008.

MATSUMURA G, MIYAGAWA-TOMITA S, SHIN'OKA T, IKADA Y, KUROSAWA H: First evidence that bone marrow cells contribute to the construction of tissue-engineered vascular autografts in vivo. Circulation 108: 1729-1734, 2003.

MATSUURA JH, BLACK KS, LEVITT AB, ROSENTHAL D, WELLONS ED, FALLON MT, DAVENPORT CK, GOODMAN CL, PAGELSEN ND, OLLERENSHAW JD: Cellular remodeling of depopulated bovine ureter used as an arteriovenous graft in the canine model. J Am Coll Surg 198: 778-783, 2004.

MCALLISTER TN, MARUSZEWSKI M, GARRIDO SA, WYSTRYCHOWSKI W, DUSSERRE N, MARINI A, ZAGALSKI K, FIORILLO A, AVILA H, MANGLANO X, ANTONELLI J, KOCHER A, ZEMBALA M, CIERPKA L, DE LA FUENTE LM, L'HEUREUX N: Effectiveness of haemodialysis access with an autologous tissue-engineered vascular graft: a multicentre cohort study. Lancet 373: 1440-1446, 2009.

MEINHART J, DEUTSCH M, ZILLA P: Eight years of clinical endothelial cell transplantation. Closing the gap between prosthetic grafts and vein grafts. ASAIO J 43: M515-M521, 1997.

MET R, VAN LIENDEN KP, KOELEMAY MJ, BIPAT S, LEGEMATE DA, REEKERS JA: Subintimal angioplasty for peripheral arterial occlusive disease: a systematic review. Cardiovasc Intervent Radiol 31: 687-697, 2008.

MIRZAIE M, SCHMITTO JD, TIRILOMIS T, FATEHPUR S, LIAKOPOULOS OJ, TEUCHER N, DÖRGE H, SCHÖNDUBE FA: Surgical management of vascular graft infection in severely ill patients by partial resection of the infected prosthesis. Eur J Vasc Endovasc Surg 33: 610-613, 2007.

MOAWAD J, GAGNE P: Adjuncts to improve patency of infrainguinal prosthetic bypass grafts. Vasc Endovascular Surg 37: 381-386, 2003.

MUTO A, FITZGERALD TN, PIMIENTO JM, MALONEY SP, TESO D, PASZKOWIAK JJ, WESTVIK TS, KUDO FA, NISHIBE T, DARDIK A: Smooth muscle cell signal transduction: implications of vascular biology for vascular surgeons. J Vasc Surg 45 (Suppl A): A15-A24, 2007.

NEZIĆ DG, KNEZEVIĆ AM, MILOJEVIĆ PS, DUKANOVIĆ BP, JOVIĆ MD, BORZANOVIĆ MD, NESKOVIĆ AN: The fate of the radial artery conduit in coronary artery bypass grafting surgery. Eur J Cardiothorac Surg 30: 341-346, 2006.

NIKLASON LE, GAO J, ABBOTT WM, HIRSCHI KK, HOUSER S, MARINI R, LANGER R: Functional arteries grown in vitro. Science 284: 489-493, 1999.

NISHIBE T, KONDO Y, MUTO A, DARDIK A: Optimal prosthetic graft design for small diameter vascular grafts. Vascular 15: 356-360, 2007.

NOISHIKI Y, TOMIZAWA Y, YAMANE Y, MATSUMOTO A: Autocrine angiogenic vascular prosthesis with bone marrow transplantation. Nat Med 2: 90-93, 1996.

NORGREN L, HIATT WR, DORMANDY JA, NEHLER MR, HARRIS KA, FOWKES FG: TASC II Working Group. Inter-Society Consensus for the Management of Peripheral Arterial Disease (TASC II). J Vasc Surg 45 (Suppl S): S5-S67, 2007.

NORTON L, EISEMAN B: Replacement of portal vein during pancreatectomy for carcinoma. Surgery 77: 280-284, 1975.

O'BRIEN TP, WALSH MT, KAVANAGH EG, FINN SP, GRACE PA, McGLOUGHLIN TM: Surgical feasibility study of a novel polytetrafluoroethylene graft design for the treatment of peripheral arterial disease. Ann Vasc Surg 21: 611-617, 2007.

PAMULA E, BAČÁKOVÁ L, FILOVÁ E, BUCZYNSKA J, DOBRZYNSKI P, NOSKOVÁ L, GRAUSOVÁ L: The influence of pore size on colonization of poly(L-lactide-glycolide) scaffolds with human osteoblast-like MG 63 cells in vitro. J Mater Sci Mater Med 19: 425-435, 2008.

PANNETON JM, HOLLIER LH, HOFER JM: Multicenter randomized prospective trial comparing a pre-cuffed polytetrafluoroethylene graft to a vein cuffed polytetrafluoroethylene graft for infragenicular arterial bypass. Ann Vasc Surg 18: 199-206, 2004. 
QUARMBY JW, BURNAND KG, LOCKHART SJ, DONALD AE, SOMMERVILLE KM, JAMIESON CW, BROWSE NL: Prospective randomized trial of woven versus collagen-impregnated knitted prosthetic Dacron grafts in aortoiliac surgery. Br J Surg 85: 775-777, 1998.

RADEMACHER A, PAULITSCHKE M, MEYER R, HETZER R: Endothelialization of PTFE vascular grafts under flow induces significant cell changes. Int J Artif Organs 24: 235-242, 2001.

RAHLF G, URBAN P, BOHLE RM: Morphology of healing in vascular prostheses. Thorac Cardiovasc Surg 34: 4348, 1986.

RÉMY-ZOLGHADRI M, LAGANIÈRE J, OLIGNY JF, GERMAIN L, AUGER FA: Endothelium properties of a tissue-engineered blood vessel for small-diameter vascular reconstruction. J Vasc Surg 39: 613-620, 2004.

RIEDEL T, BRYNDA E, DYR JE, HOUSKA M: Controlled preparation of thin fibrin films immobilized at solid surfaces. J Biomed Mater Res A 88: 437-447, 2009.

RICOTTA JJ: Vascular conduits: an overview. In: Vascular Surgery. RB RUTHERFORD (ed), Elsevier-Saunders, Philadelphia, 2005, pp 688-695.

RIHA GM, LIN PH, LUMSDEN AB, YAO Q, CHEN C: Review: application of stem cells for vascular tissue engineering. Tissue Eng 11: 1535-1552, 2005.

ROLL S, MÜLLER-NORDHORN J, KEIL T, SCHULZ H, EIDT D, GREINER W, WILLICH SN: Dacron vs. PTFE as bypass materials in peripheral vascular surgery - systematic review and meta-analysis BMC Surgery 8: 22, 2008.

SALACINSKI HJ, TIWARI A, HAMILTON G, SEIFALIAN AM: Cellular engineering of vascular bypass grafts: role of chemical coatings for enhancing endothelial cell attachment. Med Biol Eng Comput 39: 609-618, 2001.

SARJEANT JM, RABINOVITCH M: Understanding and treating vein graft atherosclerosis. Cardiovasc Pathol 11: 263-271, 2002.

SARKAR S, SALACINSKI HJ, HAMILTON G, SEIFALIAN AM: The mechanical properties of infrainguinal vascular bypass grafts: their role in influencing patency. Eur J Vasc Endovasc Surg 31: 627-636, 2006.

SASAKI H: The right gastroepiploic artery in coronary artery bypass grafting. J Card Surg 23: 398-407, 2008.

SATO S, NITTA Y, SAIKI Y, KAWAMOTO S, IGUCHI A, KAKU M, TABATA Y, TABAYASHI K: Enhanced perigraft angiogenesis prevents prosthetic graft infection. Ann Thorac Surg 86: 1278-1284, 2008.

SAUVAGE LR: Dacron arterial grafts. In: Vascular Graft Update: Safety and Performance. HE KAMBIC, A KANTROWITZ, P SUNG (eds), ASTM Publication, Williamsburg, 1986, pp 16-24.

SCHMIDT CE, BAIER JM: Acellular vascular tissues: natural biomaterials for tissue repair and tissue engineering. Biomaterials 21: 2215-2231, 2000.

SCHOUTEN O, HOEDT MT, WITTENS CH, HOP WC, VAN SAMBEEK MR, VAN URK H: VASCAN Study Group. End-to-end versus end-to-side distal anastomosis in femoropopliteal bypasses; results of a randomized multicenter trial. Eur J Vasc Endovasc Surg 29: 457-462, 2005.

SCHWARZBACH MH, HORMANN Y, HINZ U, LEOWARDI C, BÖCKLER D, MECHTERSHEIMER G, FRIESS H, BÜCHLER MW, ALLENBERG JR: Clinical results of surgery for retroperitoneal sarcoma with major blood vessel involvement. $J$ Vasc Surg 44: 46-55, 2006.

SCOTT EC, GLICKMAN MH: Conduits for hemodialysis access. Semin Vasc Surg 20: 158-163, 2007.

SEIFALIAN AM, TIWARI A, HAMILTON G, SALACINSKI HJ: Improving the clinical patency of prosthetic vascular and coronary bypass grafts: the role of seeding and tissue engineering. Artif Organs 26: 307-320, 2002.

SEIFALIAN AM, SALACINSKI HJ, TIWARI A, EDWARDS A, BOWALD S, HAMILTON G: In vivo biostability of a poly(carbonate-urea)urethane graft. Biomaterials 24: 2549-2557, 2003.

SHI Q, WU MH, ONUKI Y, GHALI R, HUNTER GC, JOHANSEN KH, SAUVAGE LR: Endothelium on the flow surface of human aortic Dacron vascular grafts. J Vasc Surg 25: 736-742, 1997.

SHIN H, JO S, MIKOS AG: Biomimetic materials for tissue engineering. Biomaterials 24: 4353-4364, 2003.

SHIN'OKA T, IMAI Y, IKADA Y: Transplantation of a tissue-engineered pulmonary artery. $N$ Engl J Med 344: 532$533,2001$. 
SHIN'OKA T, MATSUMURA G, HIBINO N, NAITO Y, WATANABE M, KONUMA T, SAKAMOTO T, NAGATSU M, KUROSAWA H: Midterm clinical result of tissue-engineered vascular autografts seeded with autologous bone marrow cells. J Thorac Cardiovasc Surg 129: 1330-1338, 2005.

SIEGMAN FA: Use of the venous cuff for graft anastomosis. Surg Gynecol Obstet 148: 930, 1979.

SITZMANN JV, IMBEMBO AL, RICOTTA JJ, MCMANAMA GP, HUTCHINS GM: Dimethylsulfoxide-treated, cryopreserved venous allografts in the arterial and venous systems. Surgery 95: 154-159, 1984.

SRIRAM V, PATTERSON C: Cell cycle in vasculoproliferative diseases: potential interventions and routes of delivery. Circulation 103: 2414-2419, 2001.

STARZL TE: A trip south. In: The Puzzle People: Memoirs of a Transplant Surgeon. TE STARZL (ed), University of Pittsburgh Press, Pittsburgh, 2003, pp 47-58.

STEHOUWER CD, CLEMENT D, DAVIDSON C, DIEHM C, ELTE JW, LAMBERT M, SERENI D, the EFIM Vascular Medicine Working Group: Peripheral arterial disease: a growing problem for the internist. Eur $J$ Intern Med 20: 132-138, 2009.

STEWART GJ, ESSA N, CHANG KH, REICHLE FA: A scanning and transmission electron microscope study of the luminal coating on Dacron prostheses in the canine thoracic aorta. J Lab Clin Med 85: 208-226, 1975.

SWENNE CL, BOROWIEC J, CARLSSON M, LINDHOLM C: Prediction of and risk factors for surgical wound infection in the saphenous vein harvesting leg in patients undergoing coronary artery bypass. Thorac Cardiovasc Surg 54: 300-306, 2006.

TIWARI A, SALACINSKI HJ, HAMILTON G, SEIFALIAN AM: Tissue engineering of vascular bypass grafts: role of endothelial cell extraction. Eur J Vasc Endovasc Surg 21: 193-201, 2001.

TIWARI A, SALACINSKI H, SEIFALIAN AM, HAMILTON G: New prostheses for use in bypass grafts with special emphasis on polyurethanes. Cardiovasc Surg 10: 191-197, 2002.

TIWARI A, CHENG KS, SALACINSKI H, HAMILTON G, SEIFALIAN AM: Improving the patency of vascular bypass grafts: the role of suture materials and surgical techniques on reducing anastomotic compliance mismatch. Eur J Vasc Endovasc Surg 25: 287-295, 2003.

VARA DS, SALACINSKI HJ, KANNAN RY, BORDENAVE L, HAMILTON G, SEIFALIAN AM: Cardiovascular tissue engineering: state of the art. Pathol Biol (Paris) 53: 599-612, 2005.

VARU VN, TSIHLIS ND, KIBBE MR: Basic science review: nitric oxide--releasing prosthetic materials. Vasc Endovascular Surg 43: 121-131, 2009.

VOORHEES AB Jr, JARETZKI A, BLAKEMORE AH: The use of tubes constructed from vinyon "N" cloth in bridging arterial defects. Ann Surg 135: 332-336, 1952.

VROMAN L, ADAMS AL: Identification of rapid changes at plasma-solid interfaces. J Biomed Mater Res 3: 43-67, 1969.

WALPOTH BH, ROGULENKO R, TIKHVINSKAIA E, GOGOLEWSKI S, SCHAFFNER T, HESS OM, ALTHAUS $\mathrm{U}$ : Improvement of patency rate in heparin-coated small synthetic vascular grafts. Circulation 98 (Suppl II): II-319-II-324, 1998.

WATSON HR, BELCHER G, HORROCKS M: Adjuvant medical therapy in peripheral bypass surgery. Br J Surg 86: 981-991, 1999.

WEINBERG CB, BELL E: A blood vessel model constructed from collagen and cultured vascular cells. Science 231: 397-400, 1986.

WISSELINK W, MONEY SR, BECKER MO, RICE KL, RAMEE SR, WHITE CJ, KAZMIER FJ, HOLLIER LH: Comparison of operative reconstruction and percutaneous balloon dilatation for central venous obstruction. Am J Surg 166: 200-205, 1993.

WU MH, KOUCHI Y, ONUKI Y, SHI Q, YOSHIDA H, KAPLAN S, VIGGERS RF, GHALI R, SAUVAGE LR: Effect of differential shear stress on platelet aggregation, surface thrombosis, and endothelialization of bilateral carotid-femoral grafts in the dog. J Vasc Surg 22: 382-390, 1995.

XUE L, GREISLER HP: Biomaterials in the development and future of vascular grafts. J Vasc Surg 37: 472-480, 2003.

YOSHIZUMI M, ABE J, TSUCHIYA K, BERK BC, TAMAKI T: Stress and vascular responses: atheroprotective effect of laminar fluid shear stress in endothelial cells: possible role of mitogen-activated protein kinases. J Pharmacol Sci 91: 172-176, 2003. 
ZACHARIAS RK, KIRKMAN TR, CLOWES AW: Mechanisms of healing in synthetic grafts. $J$ Vasc Surg 6: 429-436, 1987.

ZARBIV G, PREIS M, BEN-YOSEF Y, FLUGELMAN MY: Engineering blood vessels by gene and cell therapy. Expert Opin Biol Ther 7: 1183-1191, 2007.

ZDRAHALA RJ: Small caliber vascular grafts. Part II: Polyurethanes revisited. J Biomater Appl 11: 37-61, 1996.

ZHANG Z, MAROIS Y, GUIDOIN RG, BULL P, MAROIS M, HOW T, LAROCHE G, KING MW: Vascugraft polyurethane arterial prosthesis as femoro-popliteal and femoro-peroneal bypasses in humans: pathological, structural and chemical analyses of four excised grafts. Biomaterials 18: 113-124, 1997.

ZILLA P, BEZUIDENHOUT D, HUMAN P: Prosthetic vascular grafts: wrong models, wrong questions and no healing. Biomaterials 28: 5009-5027, 2007. 